\title{
Forming Bachelors' Labor Actions in Teacher Training When Studying Disciplines of Mathematical and Natural Science Cycle
}

\author{
Tatyana I. Anisimova \\ Kazan (Volga Region) Federal University, RUSSIA
}

•Received 17 June $2015 \bullet$ Revised 22 August $2015 \bullet$ Accepted 19 September 2015

The urgency of the problem stated in the article is due to the fact that in connection with the adoption in Russia of the Professional Standard for Teachers, Bachelors of teacher education should be fully ready for the implementation of their professional activities in accordance with the structure and content of labor actions specified in the Standard. The purpose of the article is to present the experience of the teachers of Elabuga Institute of Kazan (Volga region) Federal University in the development of the curriculum module, aimed at the development of the following labor actions: development of skills related to information and communication technologies; formation of common cultural competence and understanding the place of the subject in the overall picture of the world. The leading approach to the study of this problem is the analysis of the existing Bachelor training programs in teacher education, which leads to the conclusion about the need in practiceoriented approach to the training of future teachers. The developed curriculum module is for the discipline "Mathematics and mathematical foundations of information processing", the main purpose of which is to provide students with skills enabling them to master the techniques of search and critical appraisal of natural science information, methods of mathematical processing of the results of educational research, and to involve students in the professional activities beginning with the first year of the study, which will enable them to become highly qualified teachers of the future.

Keywords: competence, labor actions, pedagogical education, teacher professional standard, training of Bachelors in teacher education

\section{INTRODUCTION}

A pilot project was launched in Russia in the middle of 2014 for the modernization of pedagogical education The main purpose of which is to bring teacher training programs in line with the requirements of the professional standard for teachers (PST) (Professional Standard, 2013). Accordingly, in this project, teachers of more

Correspondence: Tatyana I. Anisimova,

Kazan (Volga Region) Federal University, 18, Kremlyovskaya Street, Kazan, 420008, Russia.

E-mail: anistat@mail.ru

doi: 10.29333/iejme/298 
than twenty leading Russian universities started to develop new (modernized) modules of the main professional educational programs: applied and academic Bachelor training programs, research and professional (educational) Master programs, all aimed at creating a willingness or ability to perform labor actions specified in PST.

Some academic works (Margolis, 2014a; Margolis, 2014b; Safronova \& Bysik, 2014) indicate that this may be achieved by:

- radical increase in professional qualities of students receiving educational training;

- changes in the content and technology of teacher training, so as to ensure the implementation of the new professional standard, new standards of school and pre-school education;

- improvement of the efficiency of universities and teacher training colleges, implementing teacher training programs.

The module "Disciplines of Mathematical and Natural Science cycle: scientific and mathematical knowledge in educational practice" that was developed by the teachers of Elabuga Institute of Kazan (Volga) Federal University (EI KFU) is aimed at the formation of the ability to perform labor actions specified in the Teacher Professional Standard.

The module program and its implementation is widely represented in the works of University teachers (Anisimova \& Sabirova, 2015; Galimullina \& Krainova, 2015; Lyubimova \& Batyrev, 2015; Sabirova, 2015).

In modern conditions, professionals working in the field of education have to deal with a large volume of information. Correct processing of the information and acting upon it with the right decisions largely determines the success of the work. Without the use of mathematical methods it is now hard to imagine any kind of work with such information: its acquisition, processing, analysis, and forecasting. Knowledge of methods and understanding their essence allows for the choice of means to address both educational problems and challenges in future professional activities (Abdrafikova \& Konopatskaya, 2014).

Teacher's professional activity determines the success of the development of society and the country as a whole. In recent years, many countries, for example in Finland, demonstrate high quality school education in PISA international studies, with the selection of candidates for the post of teacher (in any subject) is based on the analysis of test results that identify the applicant's skills in numeracy, literacy and problem solving, and the ability to handle information and evaluate it critically.

In this regard, while developing the Main Professional Educational Program (MPEP), the module "Disciplines of Mathematical and Natural Science Cycle: scientific and mathematical knowledge in educational practice", has been designed so as to include the discipline "Mathematics and Mathematical Foundations of Information Processing" (MMFIP) as its base component. Research on the use of mathematical processing of information in the teacher's professional activities has been conducted for a long time, and some results indicate the successful formation of certain labor actions specified in PST, or their component parts (Anisimova \& Krasnova, 2015; Gilmullin, 2009, 2015).

The developed MMFIP discipline program aims: to provide students with a mastery of techniques for searching and the critical appraisal of natural science information, to perform mathematical processing of the results of pedagogical activity according to the presented data, to represent the data in tables, charts, graphs and to interpret them in the practice of university-school networking. 


\section{METHODOLOGICAL FRAMEWORK}

The study used the following methods: analysis of normative documents in the sphere of education and results of students' performance, testing of students, aimed at identifying the level of labor actions' formation.

The study was conducted in three phases:

- In the first stage - preparatory - the current state of the investigated problem in pedagogical theory and practice was analyzed, and the program of the discipline MMFIP as part of the module was designed;

- In the second stage - the main stage - testing of the module "Disciplines of Mathematical and Natural Science cycle: scientific and mathematical knowledge in educational practice" was performed at School No.9 in Elabuga, attended by 127 students of three faculties of EI KFU enrolled in the direction of training "Teacher Education";

- In the third stage - the final stage - systematization, interpretation and synthesis of the research results was carried out; theoretical conclusions were refined.

\section{RESULTS}

\section{Program development}

According to the Federal State Educational Standard of Higher Education, as a result of mastering Bachelor programs, the graduate in the direction 44.03.05 Teacher education must have common cultural competence, in particular CC-1 (the ability to use the basics of philosophical and socio-humanitarian knowledge for the formation of a scientific outlook) and CC-3 (the ability to use scientific and mathematical knowledge to guide people in the modern information space) formed Competences, formed as a result of mastering the discipline and providing the student's ability to implement labor actions are presented in Table 1.

Table 1 shows that competence CC-1 involves implementation of labor actions specified in the PST and meeting the requirements of the FSES. Accordingly, the student must know:

- basic concepts of natural science (K1);

- the most general laws of science development and its historic periods (K2); 
- outlines of key trends and directions of modern science development (K3);

Table 1. Competences formed within the discipline MMFIP

\begin{tabular}{|c|c|c|c|}
\hline abor Actions & Competences & Educational Result & $\begin{array}{l}\text { The forms and methods of } \\
\text { teaching that promote the } \\
\text { formation and development } \\
\text { of competence }\end{array}$ \\
\hline \multirow[t]{2}{*}{$\begin{array}{l}\text { Formation of skills } \\
\text { related to information } \\
\text { and communication } \\
\text { technologies (1.1.8.) }\end{array}$} & \multirow[t]{2}{*}{ CC-3 } & $\begin{array}{l}\text { Willingness to learn and use application software, } \\
\text { including educational, in general pedagogical } \\
\text { activities. }\end{array}$ & $\begin{array}{l}\text { Workshops. } \\
\text { Processing of pedagogical } \\
\text { experiment in school }\end{array}$ \\
\hline & & $\begin{array}{l}\text { Application of mathematical tools and ICT in solving } \\
\text { educational problems. }\end{array}$ & \\
\hline $\begin{array}{l}\text { Formation of common } \\
\text { cultural competence } \\
\text { and understanding of } \\
\text { the place of the subject } \\
\text { in the overall picture of } \\
\text { the world (2.3.1.) }\end{array}$ & CC-1 & $\begin{array}{l}\text { Readiness to independently obtain natural science } \\
\text { knowledge in the information space; analyze the } \\
\text { data and create a natural science texts as part of } \\
\text { teacher's professional activities. }\end{array}$ & $\begin{array}{l}\text { Workshops. Presentation of self- } \\
\text { designed products (essay on the } \\
\text { history of mathematics) for public } \\
\text { discussion, remote independent } \\
\text { work. Interactive lecture, small } \\
\text { group work, participation in } \\
\text { discussions and debates }\end{array}$ \\
\hline
\end{tabular}

be able to:

- work with the conceptual apparatus of science, to choose the best definition to the concepts, and if necessary, to formulate them independently (S1);

- search for natural science information, including information space with the use of keywords, analyze and evaluate the obtained information (S2);

- create, apply and transform signs and symbols, models and schemes for solving educational and cognitive tasks (S5).

Competence CC-3 involves implementation of labor actions specified in the PST and meeting the requirements of the FSES. Accordingly, the student must know:

- the basis of mathematical apparatus for solving practical problems of obtaining, storage, processing and transmission of information (K8);

- the scope of the simple basic mathematical models in the educational field K9);

be able to:

- use the simple basic mathematical models in educational activities (S9);

- carry out mathematical processing of pedagogical experiment data on the computer, present information visually (S10);

- use modern educational technologies, including information technologies and digital educational resources (S11);

- work with Web browsers, text editors, table processors, use ICT in learning and independent work (S12);

- search for and critically evaluate mathematical, natural science information, as well as from the field of ICT in education (S14);

- develop and implement application software in training activities (S15);

- create an e-portfolio of learning and professional achievements (S18).

The discipline involves two-way interaction with educational institutions implementing programs of general education, i.e.:

1. inviting teachers-supervisors to conduct master classes;

2. joint thematic workshops (debates, conferences, round tables);

3. interaction in social network communities of educators (nsportal.ru, easyen.ru etc.); 
4. obtaining information from schools for mathematical processing and interpretation of results.

\section{Place of the discipline in the module structure}

Discipline MMFIP refers to the basic part of the module "Disciplines of Mathematical and Natural Science Cycle: scientific and mathematical knowledge in educational practice".

The curriculum is designed for Bachelors who start teacher education, and is implemented in the process of networking with schools; it has practical orientation, which is manifested in organizing students' activities, aimed at the formation of an eportfolio that can be used in teaching practice.

Studying the discipline is based on competencies, formed in the process of studying high school subjects "Geometry", "Algebra and Basics of Analysis", "Informatics" and the discipline "Natural science picture of the world", studying which lays the foundation for the competencies formed in the module, as they are based on understanding the nature of science, the specifics of scientific knowledge and the most important laws and tendencies of its development.

Competences, developed in the process of studying this discipline will be required in the course of the study of the subjects "Evaluation of the effectiveness of the educational process" of the variable part of the module "Disciplines of professional cycle of basic training: Design and implementation of educational processes", "Educational diagnosing" of the variable part of the module "Theoretical and experimental activities: Teacher's research and experimental activity", "School psycho-diagnostics" of the basic part of the module "Psychology and pedagogy of students' development: Practice of student-centered education".

The event that provides the student's entrance into the study of the discipline is entrance diagnostics, the objective of which is to identify the students' degree of readiness to apply mathematical methods in solving applied problems and interpreting the obtained results. To achieve this, students are given a set of tasks in mathematics that reflect their future teaching activities (work with tables, graphs, etc.) during the first, introductory lesson.

On completing the tasks, the students are to evaluate themselves, i.e. answer the questions:

1. What I managed to do best was...

2. The main difficulties include...

3. I still have difficulty in...

4. I wish I could...

This analysis helps students and teachers to predetermine the purpose of further work and correct the educational route.

\section{Methods of studying the discipline MMFIP}

The discipline of curriculum includes nine interrelated sections that the students study consistently within two weeks, so all the material is divided into two parts:

1. Mathematical tools of information representation. Elements of set theory, graph theory, algebra, logics when dealing with information.

2. Elements of combinatorics, probability theory and mathematical statistics when dealing with information.

Each part of the discipline represents a step-cluster of educational and professional activities towards the development of students' ability to act as a teacher in the conditions of active interaction with members of their team, with school and university teachers, displaying scientific, creative thinking, the ability to evaluate their performance, and other students' activities, make forecasts, and correct errors. 
The study of the discipline MMFIP involves interactive learning technologies, such as:

- The joint problem lecture of the teacher and the teacher-supervisor that discloses the use of different types of mathematical models (graphs, tables) in reporting at school;

- A master-class of the teacher-supervisor on the use of statistical methods in educational research;

- Role-playing game "Mathematics in the life of one school day" (amendments to the timetable, formation of small groups in the class, analysis of students' absenteeism);

- Defending of the e-portfolio.

An e-portfolio technology is used to collect, store, develop, present individually significant results (academic, scientific, personal). The purpose of developing an eportfolio is to enable students to highlight and reflect on their strengths and weaknesses using formative feedback, enabling teachers to support students' success and preferences in appropriate ways. Making an e-portfolio, students purposefully collect works that demonstrate their competence and educational achievements in the process of mastering the module.

When constructing a lecture course, it is important to consider not only the content, but the logic of each section of the presentation. It is significant to understand the structure of the course clearly, and to be able to identify the basic concepts in all main sections. The teacher should pay attention to the wealth of intrasubject and intersubject links between the sections of the course, to the specific examples of appropriate use of the elements of mathematical processing of information in teaching.

The workshops combine theory and practice. Students acquire the necessary labor actions and practical skills in the application of mathematical methods of information processing in practice. As part of networking, students have an opportunity to join the school working process, to analyze the teacher's work, which allows demonstrating the application of the mathematical apparatus of ICT-based information processing. The most effective form of practice is teaching others, i.e. immediate application of knowledge and skills in practice - 90\% (Golovanova, Asafova, \& Telegina, 2014; Uşun, 2009; Schelfhout et al., 2006).

Students' independent work is a kind of educational software that supports the development of target readiness for professional self-education and is a didactic means of the educational process, an artificial pedagogical structure for organizing and managing students' activities.

The following types of independent work are used:

- Search of information on the Web "Internet";

- Work with lecture notes, required textbooks and manuals;

- Solution of additional tasks;

- Abstract preparation and defense;

- Preparation for tests;

- Collection of statistical information in school;

- Drafting tasks with practice-oriented content;

- Preparation of an e-portfolio.

Monitoring is carried out in the form of tests, solving, in which the student must demonstrate the ability to build a mathematical model of the problem statement, to solve the problem, to interpret the results, to process the statistical information gathered as part of networking, to give the visualized form of the results.

\section{Assessment means of the discipline}


Landmark control was conducted on a basis of evaluation funds and by means of the e-portfolio defense where the students showed an adequate ability to assess their own achievements.

Table 2 shows part of tests aimed at verifying the level of formation of University students' labor actions while studying the discipline MMFIP.

The tests that allowed checking the level of formation of all labor actions declared in the module have been developed throughout the whole module.

\section{DISCUSSIONS}

Teacher professional standard, in one form or another, has been considered by a number of researchers (Mayer, Mitchell, Macdonald, \& Bell, 2005; Nyshanova, Baimukhanbetov, Abdigapbarova, \& Mukhamedzhanov, 2014; Thomas \& Kearney, 2008).

In particular, the work of Bazurina (2006) notes that beginning with the first year of training in higher pedagogical institutions, such students' qualities as activity, initiative, and ability to understand the essence of the problem posed and solve it with the help of the acquired knowledge and skills are necessary to be developed.

However, the analysis of the works shows, that they do not specify teachers' competences with practice-oriented focus, which are reflected in the curriculum developed by us. 
Table 2. Tests verifying the ability to perform labor actions specified in PST

\begin{tabular}{lll}
\hline Labor action & Knowledge and Skills & Test w \\
\hline Formation of skills & S10. To be able to carry out & 1. Teach \\
related to information & mathematical processing of & result n \\
and communication & pedagogical experiment on the & 8; 10; 9 \\
technologies (1.1.8) & computer, prepare a visual & Specify \\
& presentation of information. & 1 1) 6 \\
& S11. To apply modern educational & 2 ) 7 \\
& technology, including information & 3 ) 8 \\
& and digital educational resources. & $4)$
\end{tabular}

S15. To be able to develop and apply Justification of the correct answer:

the application software of

educational activity.

To find the answer you need to find a difference between the K8. Know the basics of mathematical maximum and minimum score of $10-2=8$. With a large amount

Formation of skills related to information and communication technologies (1.1.8) apparatus for solving practical problems of obtaining, storage, processing and transmission of information.
S9. To be able to apply simple mathematical models in basic education activities.

S10. To be able to carry out mathematical processing of pedagogical experiment on the computer, visually present information.

K8. Know the basics of mathematical Box I3: the total number of marks of Absalyamova Azalia apparatus for solving practical problems of obtaining, storage, processing and transmission of information. K9. To know the scope of the simple basic mathematical models in the educational field. were entered in the table MS Excel:

Cell C3: the number of fives of Absalyamova Azalia

Cell D3: the number of fours of Absalyamova Azalia

Cell E3: the number of threes of Absalyamova Azalia

Cell F3: the number of twos of Absalyamova Azalia Indicate on which formula the quality of knowledge of Absalyamova Azalia is found:

1) $=(\mathrm{C} 3 * 1+\mathrm{D} 3 * 0,64+\mathrm{E} 3 * 0,32+\mathrm{F} 3 * 0,16) / \mathrm{G} 3 * 100$

2) $=(\mathrm{C} 3+\mathrm{D} 3+\mathrm{E} 3)^{*} 100 / \mathrm{I} 3$

3) $=(\mathrm{C} 3+\mathrm{D} 3) * 100 / \mathrm{I} 3$

4) $=(\mathrm{C} 3+\mathrm{E} 3) * 100 / \mathrm{I} 3$

Justification of the correct answer: of data, it is best to use MS Excel, using the function $=$ MAX, $=$ MIN. The correct answer is 3 )

2. The class teacher presented information about students in the class, including the number of fives, fours, threes and twos, that students received in the $1^{\text {st }}$ term of 2014-2015 school year. All data

To perform the job you need to build a formula

$=$ (The number of "5s" + the number of "4s") x 100\% / total number of assessments of the pupil. Correct answer is 3)

3. Formula «(P3+D3)*100/M3 =» is written to calculate the values in the table editor MS Excel.

1) The formula is written incorrectly as the sign $\backslash "=\backslash$ " should be at the beginning of the formula, the rest of the formula is written correctly;

2) The formula for MS Excel is written correctly, because all the signs are in accordance with the requirements for completing the tables; and digital educational resources.

S15. To be able to develop and apply the application software of educational activity.

3) The formula is written incorrectly as a sign $\backslash "=\backslash "$ is placed at the beginning of the formula, and alphabetic characters in the cell addresses in the formula must be in Latin letters;

K8. Know the basics of mathematical 4) The formula is written incorrectly as alphabetic characters in the apparatus for solving practical problems of obtaining, storage, processing and transmission of information. addresses of cells must be in Latin letters, the rest of the formula is written correctly.

Choose the correct answer.

Justification of the correct answer:

It is necessary to enter a formula in MS Excel with the equals sign. It is necessary to MS Excel to realize that what is introduced into the cell is a formula, not data. The letter symbols in the cell addresses in the formula must be in Latin letters Therefore, the correct answer is 3) 
Formation of common K2. Know the most general laws of cultural competence development of science and its and understanding of historic periods.

the place of the subject

in the overall picture of the world (2.3.1).
4. The student prepares a report on the development of Russian science in the era of Peter I. Specify which of the famous mathematicians was a contemporary of Peter I:
1) M.V. Ostrogradskii
2) G.V. Leibniz
3) R. Descartes
4) F. Viète
Choose the correct answer.

Justification of the correct answer:

In 1697, while traveling in Europe Peter I, the Russian tsar, met G.V. Leibniz. This led eventually to Peter's approval of the creation of the Academy of Sciences in St. Petersburg, which was the beginning of the development of scientific research in Russia according to the West European model. Leibniz proposed research project in Russia related to its unique geographical location, such as the study of Earth's magnetic field, and searching the way from the Arctic to the Pacific Ocean.

\section{CONCLUSION}

In September and November 2014 the module "Disciplines of Mathematical and Natural Science cycle: scientific and mathematical knowledge in educational practice" was tested, which included the above named discipline MMFIP in School No.9 in Elabuga, Republic of Tatarstan. The testing was carried out through the collaboration of KFU Elabuga Institute teachers who were responsible for the students' studying the module disciplines and School No.9 teachers-supervisors in accordance with the developed guidelines.

The experience we obtained as the result of testing the discipline MMFIP within the framework of teaching the module "Disciplines of Mathematical and Natural Science Cycle: scientific and mathematical knowledge in educational practice", the test results of the developed assessment tools fund, preparation and defense of eportfolios have shown that the implementation of the developed program allows for creating the students' capacity for performing labor actions 1.1.8 and 2.3.1 specified in the PST when training Bachelors of Teacher education. However, the program does not provide a complete formation of the above labor actions. They will be refined in the course of the entire training in higher education; University students will be ready to fulfill these labor actions in full after graduation.

\section{ACKNOWLEDGMENTS}

The work is performed according to the Russian Government Program of Competitive Growth of Kazan Federal University.

\section{REFERENCES}

Abdrafikova, A. R., \& Konopatskaya, E. A. (2014). The case study technologies as the means of competency building approach realization in higher education of Russia. English Language Teaching, 7(12), 94-99.

Anisimova, T. I., \& Krasnova, L. A. (2015). Interactive Technologies in Electronic Educational $\begin{array}{llll}\text { Resources. International Education Studies. } & \text { 8(2), 186-194. }\end{array}$ http://dx.doi.org/10.5539/ies.v8n2p186

Anisimova, T. I., \& Sabirova, F. M. (2015). About module program "Disciplines of Mathematical and Natural Science Cycle" of the main professional educational program of applied bachelor degree in the direction of preparation "Teacher Education". Fundamental research, 2(14), 3146-3150.

Bazurina, V. M. (2006). Training future teachers of foreign languages in the UK (Ph.D. Thesis). Zhytomyr State University, Zhitomir, Ukraine. Retrieved from 
http://dissland.com/catalog_ukr/professionalmznaya_podgotovka_budushih_uchitelej_ inostrannueh_yazuekov_v_velikobritanii.html

Galimullina, E. Z., \& Krainova, A. I. (2015). Integration of interactive technologies as a means of strengthening practical orientation of bachelor of teacher education. Modern problems of science and education, 3. Retrieved from www.science-education.ru/123-18936

Gilmullin, M. F. (2009). The Historical Component of the Mathematical Methodological Culture of Students Taking the Course of Mathematics History at Teachers' Training University (Ph.D. Thesis). Ushinsky State Teachers' Training University, Yaroslavl, Russia. Retrieved from http://www.dissercat.com/content/formirovanie-istoricheskogo-komponentamatematiko-metodicheskoi-kultury-studentov-pri-obuche

Gilmullin, M. F. (2015). The experiment check of the efficiency of the historical component formation in teacher's mathematical methodological culture. International Education Studies. 8(4), 218-230. http://dx.doi.org/10.5539/ies.v8n4p218

Golovanova, I. I., Asafova, E. V., \& Telegina, N. V. (2014). Practice of online training. Kazan: Kazan University. Retrieved from http://kpfu.ru/portal/docs/F374100893/Golovanova_Asafova.pdf

Lyubimova, E. M., \& Batyrev, V. V. (2015). Continuous training and professional practice in the training of future teachers. Electronic scientific and practical periodical "Economy and Society", 11 (14). 1 Retrieved http://www.iupr.ru/domains_data/files/zurnal_14/Lyubimova\%20E.M.\%20Batyrev\% 20V.\%20V.pdf

Margolis, A. A. (2014a) Problems and prospects of teacher education in the Russian Federation. Psychological Science and Education. 19(3), 41-57.

Margolis, A. A. (2014b) Requirements for the modernization of the basic professional educational programs (BPEP) of teacher training in accordance with the professional standard of the teacher: proposals for the implementation of the activity approach to teacher training. Psychological Science and Education, 19(3), 105-126.

Mayer, D., Mitchell, J., Macdonald, D., \& Bell, R. (2005). Professional standards for teachers: a case study of professional learning. Asia-Pacific Journal of Teacher Education. 33(2), 159179. http://dx.doi.org/10.1080/13598660500121977

Nyshanova, S. T., Baimukhanbetov, B. M, Abdigapbarova, U. M., \& Mukhamedzhanov, B. K. (2014). Developing future teachers creative abilities in competence-oriented educational process of high school. Procedia - Social and Behavioral Sciences, 116, 4287 4292.http://dx.doi.org/10.1016/j.sbspro.2014.01.933

Professional standard. Teacher (teaching activities in preschool, primary general, basic general, secondary general education) (2013). Retrieved from http://www.rosmintrud.ru/docs/mintrud/orders/129/

Sabirova, F. M. (2015). On the mechanism of implementation of practice-oriented approach in teaching disciplines of mathematical and natural science cycle in pedagogical higher schools of Russia. Innovation in the modern world: a collection of articles of the International scientific and practical conference (pp.74-77). Moscow, Russia.

Safronova, M. A., \& Bysik, N. V. (2014). Description of the project of modernization of teacher education. Psychological Science and Education, 19(3), 78-86.Schelfhout, W., Dochy, F., Janssens, S., Struyven, K., Gielen, S., \& Sierens, E. (2006). Educating for learning-focused teaching in teacher training: The need to link learning content with practice experiences within an inductive approach. Teaching and Teacher Education, 22(7), 874-897. http://dx.doi:10.1016/j.tate.2006.04.003.

Thomas, S., \& Kearney, J. (2008). Teachers working in culturally diverse classrooms: implications for the development of professional standards and for teacher education. Asia-Pacific Journal of Teacher Education. 36(2), 105-120. http://dx.doi.org/10.1080/13598660801971625.

Uşun, S. (2009). Information and communications technologies (ICT) in teacher education (ITE) programs in the world and Turkey: (a comparative review). Procedia - Social and Behavioral Sciences. 1(1), 331-334. http://dx. doi:10.1016/j.sbspro.2009.01.062 